\title{
War on Waste: Implementation of solid waste Management (RA 9003) in the Municipality of Rizal
}

\author{
Catherine P. Cubebe - Cawayan, Shinju C. Lingbawan, Reny T. Putic, Marsky A. \\ Ubeňa, Ehrol C. Bayed
}

Received: 11 Nov 2021; Received in revised form: 16 Dec 2021; Accepted: 22 Dec 2021; Available online: 31 Dec 2021

(C2021 The Author(s). Published by Infogain Publication. This is an open access article under the CC BY license (https://creativecommons.org/licenses/by/4.0/).

\begin{abstract}
Even with the presence of barangay and municipal ordinances on the Solid Waste Management and other Information Education Campaign activities in the Municipality of Rizal, Kalinga, there is a need to assess how these programs were implemented. Thus this study was conducted to assess the level of awareness and solid waste management practices of households in terms of $3 R$ (reduce, reuse and recycle) and assess the effectiveness of programs on solid waste management. A descriptive research design was used in gathering data and a total of 251 households as respondents. Data gathered were analyzed and interpreted using the frequency and percentage distribution. Findings showed that households are fully aware on the solid waste management, very aware on the waste management practices in terms of $3 R$ s 9 reduce, reuse and recycle), and good in composting and disposal practices. It was found out that IEC and solid waste management programs were implemented well.
\end{abstract}

Keywords - solid waste, War on Waste, World Bank.

\section{INTRODUCTION}

\section{Background of the Study}

Solid waste is a significant sign that there is an economic development within a community. In addition, high amount of waste generation can be a sign that a region is undergoing urbanization. In cities, the higher standard of living can lead to a higher waste output compared to rural areas. According to World Bank (2001), this is reflective of the case of the Philippines where its capital and largest urban center, Metro Manila, generates almost a quarter of the country's total waste generation.

Public participation are highly required for the waste prevention and waste management. Villanueva (2013) said in order to establish a good program for the community, Information Education Campaign can be a great help. Awareness on solid waste management will affect the perception of people on garbage. People grew up thinking that garbage is garbage, and is useless. Awareness accompanied by participation is the key for community to be involved in the waste management program where effective and sustainable implementation of the proper waste management practices could be achieved.

In compliance to R.A. 9003, the Local Government Unit of Rizal has way back bought a lot owned by Ignacio Wanawan at Bulbul, Kalinga intended for sanitary landfill. But the adjacent Barangays of San Pedro prohibited the dumping of garbage in the area due to personal reasons. To resolve the issue, the LGU purchased another site to serve as new controlled dumping site at the same barangay in Sitio Andarayan owned by Ernesto Tummaman. The new site was validated by Benigno L. Espejo- Supervising Geologist, MGB-CAR and concluded that the site is suitable for the purpose. (LGU Rizal, 2014)

With the presence of barangay and municipal ordinances on the Solid Waste Management and other Information Education Campaign activities there is no data on the extent of awareness and practices of the community pertaining on RA 9003, the study aimed to assess the awareness of the communities, their practices on the execution of RA 9003 and the effectiveness of the existing 
Information Education Campaign (IEC) and programs of Local Government Unit.

\section{Objectives of the Study}

General objective: The study aimed to assess the Solid Waste Management Strategies and Practices in the Municipality of Rizal.

Specifically objective:

1. To determine the level of awareness of the residents on RA 9003.

2. To determine the practices of residents on solid waste management in terms of the 3 Rs (reduce, reuse, recycle), segregation, composting and disposal.

3. Evaluate the effectiveness of the existing information education campaign (IEC) and programs of BLGU and MLGU on the implementation of solid waste management programs.

\section{Significance of the Study}

This study was conducted to provide data on the extent of awareness and practices of the community on the implementation of RA 9003 . The results of the study will be used as guide on the updating of both barangay and municipal ordinances related to solid waste management. The study helps on additional framework on policy formulation and regulations that will promote regulations on the programs of Department of Environment and Natural Resources (DENR) that complies with RA 9003. Through this study, there will be an enhanced economic benefits as result of the $3 \mathrm{R}$ (reduce, reuse, recycle) activities. The study will serve as an evaluation of the progress of the LGU's regarding the solid waste management currently practiced by the community.

\section{Scope and Delimitation of the Study}

The study focused on the level of awareness, management practices of residents and the effectiveness of existing programs of the Local Government Unit on the selected barangays of Municipality of Rizal namely Babalag East, Babalag West and San Pascual.

Respondents were from household members.

\section{REVIEW OF RELATED LITERATURE}

Awareness of community on waste management practices has a direct effect on the actions of community regarding proper waste management. General environmental awareness and information on health risks posed by ineffective solid waste management practices are important factors which need to be continuously communicated to all sectors of the communities. With the low level of information and awareness of public regarding environmental laws, there's a difficulty in the implementation of such laws on sanitation and cleanliness. (DENR,2002).

According to the findings of the study of Paghasian (2017), once people are knowledgeable and mindful on solid waste management they will have an acceptable habit in segregating, reducing and reusing waste materials.

According to the Provision of Section 59 of Republic Act No. 9003 and by the virtue of Executive Order No. 192, Series of 1987, the DENR adopts and promulgate certain rules and regulation. Administrative Order No. 2001-34 of2001 Section 4, Rule 6, which mandates each city or municipality to municipal solid waste board that shall ensure the long term management of solid waste, as well as, incorporate the various solid waste management plan and strategies of the barangay in its jurisdiction.

Every activities of human has a contribution to the waste management. Knowing the effects of improper management, garbage problems can be prevented by practicing waste characterization and source reduction, proper collection, segregation and transfer, recycling, and composting as mandated by the law. (Aquino et al., 2013)

According to Acosta et al. (2012) the National Solid Waste Management Commission (NSWM) released the National Solid Waste Management Framework (NSWMF) that emphasized measures to encourage waste avoidance, reduction and recycling as highlighted by RA 9003 provisions on mandatory segregation at source and waste diversion targets of at least $25 \%$. According to NSWMF all LGUs, particularly barangay LGU should encourage the composting of biodegradable wastes and the establishment of materials recovery facilities (MRFs) to improve resource recovery. Collection of wastes should be incorporated with the plans of Municipal LGUs.

As indicated in RA 9003, collaborative efforts from different government unit and other relevant stakeholders to provide information dissemination regarding source reduction of wastes, reuse, recycle and composting to continue with the common goal of proper solid waste management.

Based on the result of the study of Azuelo (2016), the existing SWM strategies with identified on their study areas were: a) presence of properly designed waste bins/receptacles at conspicuous places and availability of container/receptacles for each type of waste in waste segregation; b) conduct of seminars on livelihood skills training and identification of potential markets for recyclable goods in reuse and recycling of marketable wastes; c) regular collection of municipal garbage truck and additional truck units for collection; d) provision of skills training in composting of organic waste; e) awareness on 
waste segregation and information dissemination campaigns and programs; and f) proper implementation of ecological solid waste management programs adopting an ecological solid waste management program and abiding with its policies on rules and regulations.

According to LGU Rizal (2014) the existing waste management practices in the municipality are;

a. households were trained to segregate biodegradable and non-biodegradable waste; b. biodegradable waste are processed as compost for plant fertilizer, plastics and bottles were being sold; market waste were collected twice a week by the LGU and dumped at the controlled dump site; and

c. toxic waste, used syringe and other hazardous waste were being thrown at the hospital septic tank allotted for the purpose.

\section{METHODOLOGY}

Locale of the Study

The study was conducted from August 2019 to August 2020. The study area covered the three barangays of the Rizal Municipality namely Babalag East, Babalag West and San Pascual.

\section{Research Design}

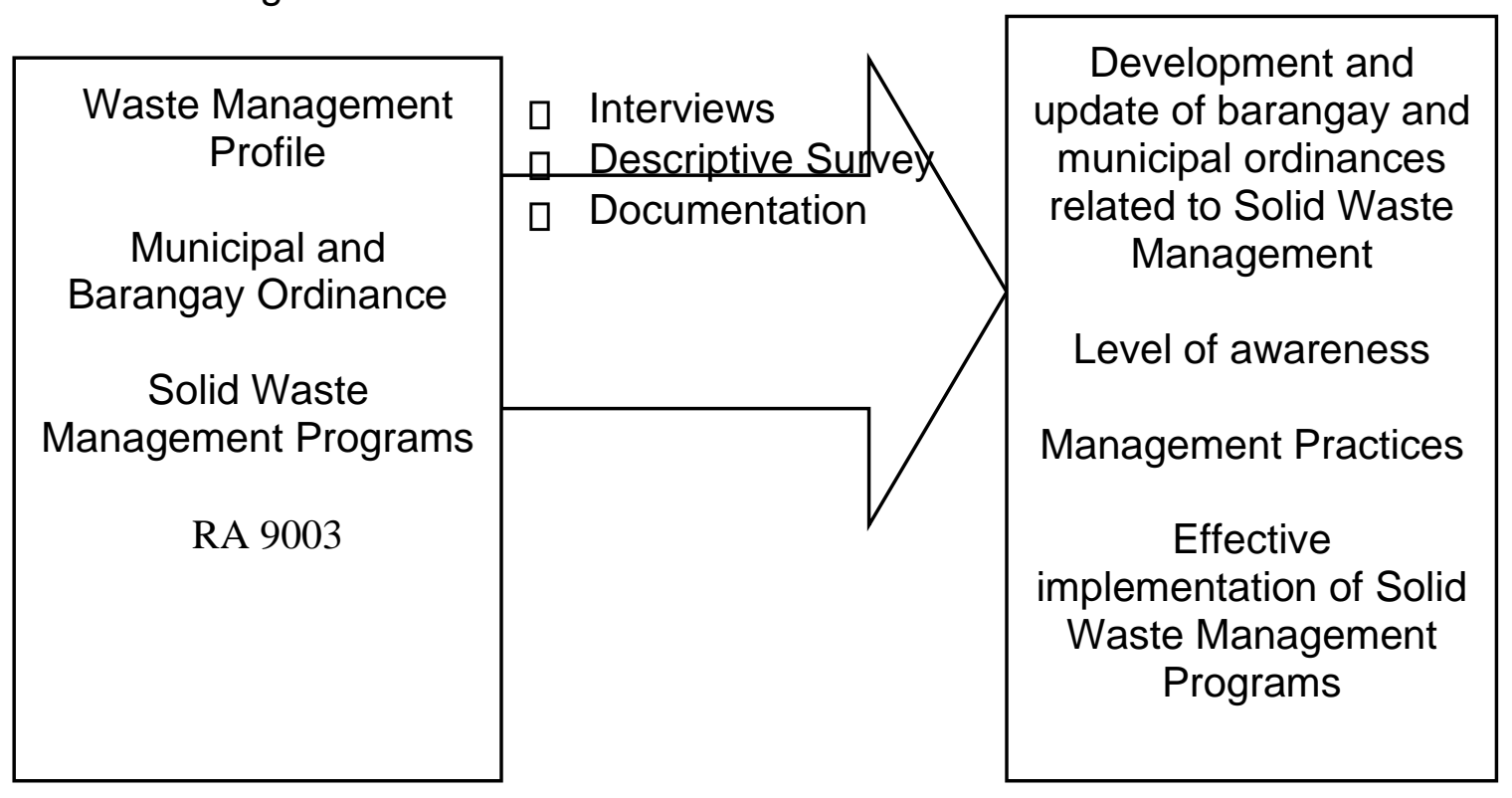

Fig.1. Process of the Study

The study used a self-administered questionnaire in determine the existing solid waste management practices, level of awareness of households and the IEC programs of LGU. Reconnaissance and ocular survey were done to document and validate the said activities.

\section{Respondents of the Study}

The respondents of the study were households. Out of 1,108 total number of households (Babalag West 492 households, San Pascual 316 and Babalag East 300), there were 251 randomly selected households, 84 respondents from Babalag East, 84 respondents from Babalag West and 83 respondents in San Pascual.

The number of respondents was determined by unrestricted random sampling with the formula:

$\mathrm{Ss}=\underline{\mathrm{NV}+\left[\mathrm{Se}^{2}\right.} \underline{(1-p)]} \quad \mathrm{NSe}+\left[\mathrm{V}^{2} \mathrm{xp}(1-\mathrm{p})\right]$

Where:

Ss $\quad=$ sample size

$\mathrm{N} \quad=$ total number of population 
$\mathrm{V}=\quad=$ standard value of $2.58 \mathrm{Se} \quad=$ sampling error $0.01 \mathrm{p}$

$=$ largest possible proportion 0.05

\section{Instrumentation}

\section{Dear Respondents,}

We are conducting a study on level of awareness, waste management practices and IEC programs regarding solid waste management of the Municipality of Rizal. The information will be treated as confidential and are for education purposes only. We seek your cooperation. Kindly fill up the questionnaires.

Name:

Barangay:

$\underline{\text { Awareness on RA } 9003}$

\section{Scale Descriptive Value}

4 Fully aware

3 Aware

2 Not so aware

1 Not aware

\begin{tabular}{|c|c|c|c|c|}
\hline \multirow{2}{*}{ DESCRIPTION } & \multicolumn{4}{|c|}{ SCALE } \\
\hline & 4 & 3 & 2 & 1 \\
\hline \multicolumn{5}{|l|}{ 1. Are you aware on the RA 9003 ? } \\
\hline \multicolumn{5}{|l|}{ 2. Are you aware on the Solid Waste Management (SWM) } \\
\hline \multicolumn{5}{|l|}{ Programs of your Barangay? } \\
\hline \multicolumn{5}{|l|}{ 3. Are you aware on the Solid Waste Management } \\
\hline \multicolumn{5}{|l|}{ Programs of your Municipality? } \\
\hline \multicolumn{5}{|l|}{ 4. Are you aware on the policies of Solid Waste } \\
\hline \multicolumn{5}{|l|}{ Management? } \\
\hline \multicolumn{5}{|l|}{ 5. Are you aware on the corresponding sanctions of any } \\
\hline \multicolumn{5}{|l|}{ violations of the SWM program? } \\
\hline \multicolumn{5}{|l|}{ 6. Are you aware on the importance of the Solid Waste } \\
\hline \multicolumn{5}{|l|}{ Management Programs of the BLGU \& MLGU? } \\
\hline \multicolumn{5}{|l|}{ 7. Are you aware on the three labels of garbage bin (color } \\
\hline \multicolumn{5}{|l|}{ coding)? } \\
\hline \multicolumn{5}{|l|}{ 8. Are you aware on the difference of biodegradable and } \\
\hline \multicolumn{5}{|l|}{ non-biodegradable? } \\
\hline \multicolumn{5}{|l|}{ 9. Can you identify biodegradable from non-biodegradable? } \\
\hline 10. Do you know how to do waste minimization practices & & & & \\
\hline like reuse, recycle and reduce? & & & & \\
\hline
\end{tabular}

Scale Descriptive Value

$4 \quad$ Always

3 Often 


$\begin{array}{ll}\mathbf{2} & \text { Seldom } \\ \mathbf{1} & \text { Never }\end{array}$

\section{REDUCE}

\section{DESCRIPTION}

\section{SCALE}

$\begin{array}{llll}4 & 3 & 2 & 1\end{array}$

1. Do you bring eco-bag when going to the market to minimize the use of cellophane bags?

2. Do you bring water in reusable water bottles than buying water in one- used plastic bottles?

3. Do you pack my lunch in reusable lunchbox so that I can't buy wrapped/packed food at the school?

4. Do you prefer to use re-usable things than single use things?

5. Are you cautious and responsible to every waste you produce?

\section{REUSE}

1. Do you reuse old things than buying new one?

2. Do you reuse old materials/cloths in their other uses?

3. Do you reuse eco-bags/grocery bags when going to market?

4. Do you reuse washable containers?

\section{RECYCLE}

1. Do you convert waste materials into new useful things?

2. Do you design plastic wastes into decorations?

3. Do you initiate generating-income out of waste materials?

4. Do you sell plastic bottles or any waste products?

\section{SEGREGATION}

1. Do you segregate biodegradable (paper, banana peels, cardboard, and vegetables) and nonbiodegradable

(plastic, tin cans, and others)?

2. Do you segregate recyclable items for collection?

3. Do you segregate biodegradable (paper, banana peels, cardboard, and vegetables) and nonbiodegradable (plastic, tin cans, and others)?

\section{COMPOSTING AND DISPOSAL}

1. Do you throw your garbage on garbage bins?

2. Do dispose biodegradable wastes into a compost pit or backyard?

3. Do you throw waste materials in common open dumps or backyard?

4. Do you burn your garbage?

5. Do you dispose your garbage thru the municipal collection dump truck?

6. Do you dispose recyclables in the MRF?

\section{EFFECTIVENESS OF EXISITING IEC AND PROGRAMS}

1. Do you practice the waste management campaigns and programs of the barangay?

2. Do you follow the signage about waste disposal on your barangay? 
3. Do you follow the waste segregation (color scheme of waste bins) on public places?

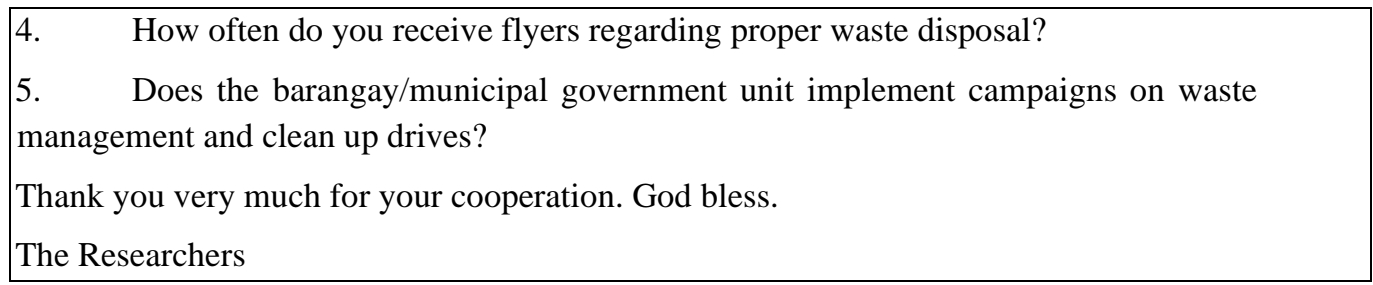

Data Gathering

The study is a descriptive research design. Face-to-face interviews with the respondents was conducted using the interview guide questionnaire. The content of the questionnaire survey is the level of awareness and their practices pertaining to the solid waste management and the effectiveness of campaigns and program of the Local Government Unit. It was explained to the respondents before the answering. The purpose of the interview was to verify the information that the respondents will give. The respondents about their awareness with a description of fully aware (4), aware (3), not so aware (2) and not aware (1) of the Solid Waste Management Programs and their practices on the Solid Waste Management as always (4), often (3), seldom (2) and never (1).

Actual observations and site visits were done to validate the answer of respondents.

Data Analysis

The data gathered were tallied and recorded for statistical treatment, analysis and interpretation. The following tools were used in the analysis of data will be adopted from Paghasian (2017): Percentage Distribution Formula. This was used to summarize the variables under study.

Formula:

$P=f / n \times 100$

Where: $P=$ percentage $f=$ frequency $n=$ total number of respondents

Weighted Mean. This was used to determine the level of awareness and practices on solid waste management of the respondents.

Formula:

Where: $\mathrm{X}=$ weighted mean $\mathrm{f}=$ frequency

$\Sigma \mathrm{fx}=$ summation of weighted means

To interpret the level of awareness on solid waste management, the scale below

was used:

$$
3.25-4.00 \quad \text { Very High }
$$

$$
\begin{array}{ll}
2.50-3.24 & \text { High } \\
1.75-2.49 & \text { Low } \\
1.00-1.74 & \text { Very Low }
\end{array}
$$

To interpret the solid waste management practices, the scale below was used:

$\begin{array}{ll}3.25-4.00 & \text { Very Good } \\ 2.50-3.24 & \text { Good } \\ 1.75-2.49 & \text { Fair } \\ 1.00-1.74 & \text { Poor }\end{array}$

\section{RESULT AND DISCUSSION}

This chapter presents the results, interpretation and analyses of data gathered. The findings were presented in the following order; level of awareness, Solid Waste Management Practices in terms of Reduce, Reuse, Recycle, 
Segregation, Composting and Disposal and Effectiveness of Existing IEC and Programs.

Table 1 presents the level of awareness on RA 9003 and Waste Management

Management of the households.

\section{Table 1: Level of Awareness}

No Descriptions

$1 \quad$ Are you aware on the 107 RA 9003?

2 Are you aware on the 161

Solid Waste Management (SWM)

Programs of your Barangay?

3 Are you aware on the 159

Solid

Waste

Management

Programs of your

Municipality?

4 Are you aware on the 145 policies of Solid Was Management?

$5 \quad$ Are you aware on the 134

Awar e

Fully

Responses

Awar e Not so Not

Awar e Awar e

19

30

13

112

2.48

Low

37

45

10

3.37

Very High

GWA Interpret

ation

$32-28$

3.29 Very High

corresponding sanctions of

any violations

of the SWM program?

6

Are you aware on the 128 importance

of the 53

Waste

$\begin{array}{lllll}42 & 48 & 27 & 3.13 & \text { High }\end{array}$

45

25

3.13 High

\begin{tabular}{|c|c|c|c|c|c|c|}
\hline \multicolumn{7}{|c|}{ Programs of the BLGU \& MLGU? } \\
\hline $\begin{array}{c}7 \text { Are you aware on the three labels of } \\
\text { garbage bin (color coding)? }\end{array}$ & 96 & 79 & 19 & 57 & 2.85 & High \\
\hline $\begin{array}{l}8 \text { Are you aware on the difference of } \\
\text { biodegradable and non- } \\
\text { biodegradable? }\end{array}$ & 191 & 50 & 5 & 5 & 3.70 & Very High \\
\hline $\begin{array}{l}9 \text { Can you identify biodegradable from } \\
\text { non-biodegradable? }\end{array}$ & 196 & 50 & 2 & 3 & 3.75 & Very High \\
\hline $\begin{array}{l}\text { Do you know how to do waste } \\
\text { minimization practices like reuse, } \\
\text { recycle and reduce? }\end{array}$ & 190 & 55 & 1 & 5 & 3.71 & Very High \\
\hline
\end{tabular}


As shown in the table, No. 9, "Identification of biodegradable from nonbiodegradable" has the highest general weighted average of 3.75 , interpreted as very high. The least general weighted average of 2.48 was No. 1, "Are you aware on Republic Act 9003?" and is interpreted as low. The weighted mean value is 3.27 interpreted as very high. This implies that households have enough knowledge on solid waste management. Even with the finding that some are not aware on RA 9003, the household have very high level of awareness on the identification of biodegradable and non-biodegradable.

Table 2: Summary on the Level of Awareness of Households Solid Waste Management

\begin{tabular}{lccc}
\multicolumn{1}{c}{ Responses } & Interpretation & Frequency & Percentage (\%) \\
\hline Fully Aware & Very High & 151 & $60.16 \%$ \\
Aware & High & 48 & $19.12 \%$ \\
Not so Aware & Low & 26 & $10.36 \%$ \\
Not Aware & Very Low & 26 & $10.36 \%$ \\
\hline
\end{tabular}

Table 2 presents the summary of assessment on the level of awareness on the solid waste management of the households. It showed that out of 251 households, $60.16 \%$ or 151 households had very high awareness on Solid Waste Management, $19.12 \%$ or 48 households had high awareness, $10.36 \%$ or 26 had low awareness and $10.36 \%$ or 26 had very low awareness. This implies that most of the households are fully aware on the solid waste management.

Table 3. Solid Waste Management Practices in Terms of Reduction

\begin{tabular}{|c|c|c|c|c|c|c|c|}
\hline \multirow[t]{2}{*}{ No } & \multirow[t]{2}{*}{ Descriptions } & \multicolumn{4}{|c|}{$\underline{\text { Responses }}$} & \multirow[t]{2}{*}{ GWA } & \multirow{2}{*}{$\begin{array}{l}\text { Interpreta } \\
\text { tion }\end{array}$} \\
\hline & & Alwa ys & Often & $\begin{array}{l}\text { Seldo } \\
\text { m }\end{array}$ & Never & & \\
\hline 1 & $\begin{array}{l}\text { Do you bring eco-bag when } \\
\text { going to the market to minimize } \\
\text { the use of cellophane bags? }\end{array}$ & 141 & 60 & 21 & 29 & 3.25 & Very Good \\
\hline 2 & $\begin{array}{l}\text { Do you bring water in reusable } \\
\text { water bottles than } \\
\text { buying water in one- used } \\
\text { plastic bottles? }\end{array}$ & 170 & 35 & 36 & 10 & 3.45 & Very Good \\
\hline 3 & $\begin{array}{l}\text { Do you pack my lunch in } \\
\text { reusable lunchbox so that I } \\
\text { can't buy wrapped/packed } \\
\text { food at the school? }\end{array}$ & 171 & 55 & 21 & 4 & 3.57 & Very Good \\
\hline 4 & $\begin{array}{l}\text { Do you prefer to use re-usable } \\
\text { things than single use things? }\end{array}$ & 173 & 55 & 17 & 6 & 3.57 & Very Good \\
\hline 5 & $\begin{array}{l}\text { Are you cautious and } \\
\text { responsible to every waste you } \\
\text { produce? }\end{array}$ & 172 & 60 & 15 & 4 & 3.59 & Very Good \\
\hline
\end{tabular}
Weighted Mean
$3.49 \quad$ Very Good

As shown in Table 3, all practices pertaining to solid waste management in terms of reduction were interpreted as very good. No. 3, “Are you cautious and responsible to every waste you produce?" has the highest average weighted average value of 3.59. The least weighted value is No. 1, "Do you bring eco-bag when going to the market to minimize the use of cellophane bags?" with a weighted average value of 3.25. The weighted mean value is 3.49 interpreted as very good. The findings showed that households have good practices in terms of reduction of wastes. They practice the use of eco-bags in 
going to the market, the use of reusable containers than buying new one and they are cautious and responsible on every waste that they are producing. Table 4 summarizes the solid waste management practices of households in terms of reduction.

Table 4: Summary on Solid Waste Management Practices of Households in Terms of Reduction

\begin{tabular}{|c|c|c|c|}
\hline Responses & Interpretation & Frequency & Percentage $(\%)$ \\
\hline Always & Very Good & 165 & 65.74 \\
\hline Often & Good & 53 & 21.11 \\
\hline Seldom & Fair & 22 & 8.76 \\
\hline Never & Poor & 11 & 4.38 \\
\hline & & 251 & $100 \%$ \\
\hline
\end{tabular}

It showed that out of $251,65.74 \%$ or 165 households had very good practices in waste reduction. Only $21.11 \%$ or 53 had good practices; $8.76 \%$ or 22 of them had fair practice and $4.38 \%$ or 11 had poor practices on waste reduction. This means that most of the households are executing good reduction practices. Table 5 presents the findings on the household practices on solid waste management on reusing.

Table 5. Solid Waste Management Practices in Terms of Reusing

\begin{tabular}{|c|c|c|c|c|c|c|c|}
\hline \multirow[t]{2}{*}{ No } & \multirow[t]{2}{*}{ Descriptions } & \multicolumn{4}{|c|}{$\underline{\text { Responses }}$} & \multirow[t]{2}{*}{ GWA } & \multirow{2}{*}{$\begin{array}{l}\text { Interpreta } \\
\text { tion }\end{array}$} \\
\hline & & Alwa ys & Often & $\begin{array}{l}\text { Seldo } \\
\text { m }\end{array}$ & Never & & \\
\hline 1 & $\begin{array}{l}\text { Do you reuse old things than buying } \\
\text { new one? }\end{array}$ & 198 & 37 & 13 & 3 & 3.71 & Very Good \\
\hline 2 & $\begin{array}{l}\text { Do you reuse old materials/cloths in } \\
\text { their other uses? }\end{array}$ & 200 & 26 & 16 & 9 & 3.66 & Very Good \\
\hline 3 & $\begin{array}{l}\text { Do you reuse eco- } \\
\text { bags/grocery bags when going to } \\
\text { market? }\end{array}$ & 198 & 29 & 14 & 10 & 3.65 & Very Good \\
\hline \multirow[t]{2}{*}{4} & Do you reuse washable containers? & 206 & 25 & 12 & 8 & 3.71 & Very Good \\
\hline & Weighted Me & ean & & & & 3.68 & Very Good \\
\hline
\end{tabular}

The table showed that all of the practices on reusing had very good interpretation. Both No. 4, "Do you reuse washable containers?" and No. 1, "Do you reuse old things than buying new one?" have the highest weighted average value of 3.71 . The least weighted average value of 3.65 is No. 3, "Do you reuse eco-bags/grocery bags when going to market?" The weighted mean value is 3.68 interpreted as very good. This implies that the households had very good practices in terms of reusing old things into new useful things and reusing of washable containers. The households are practicing the use of eco-bags when going to the market. Table 6 tells the summary of solid waste management practices of household in terms of reusing.

Table 6: Summary on Solid Waste Management Practices of Households in Terms of Reusing 
Responses

Interpretation

Frequency

Percentage (\%)

\begin{tabular}{|c|c|c|c|}
\hline Always & Very Good & 201 & 80.08 \\
\hline Often & Good & 29 & 11.55 \\
\hline Seldom & Fair & 14 & 5.58 \\
\hline Never & Poor & 7 & 2.79 \\
\hline \multicolumn{2}{|c|}{ Total } & 251 & 100 \\
\hline
\end{tabular}

The table reveals that $80.08 \%$ or 201 households had very good practices on solid waste management practices in terms of reusing, $11.55 \%$ or 29 of them had good practices, $5.58 \%$ or 14 had fair practices and 2.79 or 7 households had poorly practice. This means that most of the households have commendable practices on solid waste management in terms of reusing. Table 7 presents the solid waste management practices of households in terms of recycling.

Table 7. Solid Waste Management Practices in Terms of Recycling

\begin{tabular}{|c|c|c|c|c|c|c|c|}
\hline \multirow[t]{2}{*}{ No } & \multirow[t]{2}{*}{ Descriptions } & \multicolumn{4}{|c|}{$\underline{\text { Responses }}$} & \multirow[t]{2}{*}{ GWA } & \multirow{2}{*}{$\begin{array}{l}\text { Interpreta } \\
\text { tion }\end{array}$} \\
\hline & & Alwa ys & Often & $\begin{array}{l}\text { Seldo } \\
\text { m }\end{array}$ & Never & & \\
\hline 1 & $\begin{array}{l}\text { Do you convert waste } \\
\text { materials into new useful } \\
\text { things? }\end{array}$ & 136 & 56 & 20 & 39 & 3.15 & Good \\
\hline 2 & $\begin{array}{l}\text { Do you design plastic wastes } \\
\text { into decorations? }\end{array}$ & 126 & 62 & 22 & 41 & 3.09 & Good \\
\hline 3 & $\begin{array}{l}\text { Do you initiate generating- } \\
\text { income out of waste materials? }\end{array}$ & 184 & 45 & 8 & 14 & 3.59 & Very Good \\
\hline \multirow[t]{2}{*}{4} & $\begin{array}{l}\text { Do you sell plastic bottles or } \\
\text { any waste products? }\end{array}$ & 195 & 27 & 19 & 10 & 3.62 & Very Good \\
\hline & $\mathrm{We}$ & ted Mean & & & & 3.36 & Very Good \\
\hline
\end{tabular}

The table displayed that the highest weighted average of 3.62 is No. 4, "Do you sell plastic bottles or any waste products?" interpreted as very good. The lowest weighted average is 3.09 that fell on No. 2, "Do you design plastic wastes into decorations?" that is interpreted as good. The weighted mean value was 3.36 and is interpreted as very good. This showed that the households are very good in initiating income generating activities out of waste material and selling plastic bottles or waste products. The households are good in converting waste materials into new useful things such as decorations. Table 8 reveals the summary of solid waste practices of households in terms of recycling.

Table 8: Summary on Solid Waste Management Practices of Households in Terms of Recycling

\begin{tabular}{|c|c|c|c|}
\hline Responses & Interpretation & Frequency & Percentage $(\%)$ \\
\hline Always & Very Good & 160 & 63.74 \\
\hline Often & Good & 48 & 19.12 \\
\hline Seldom & Fair & 17 & 6.77 \\
\hline Never & Poor & 26 & 10.36 \\
\hline & & 251 & $100 \%$ \\
\hline
\end{tabular}

It showed that out of 251 households, $63.74 \%$ or 160 had very good practices on solid waste management in terms of recycling, $19.12 \%$ or 48 had good practices, $6.77 \%$ or 17 had fair practice and $10.36 \%$ or 26 had poor practices in recycling. 
This indicates that most of the households do not practice waste recycling regularly. Table 9 summarizes the solid waste management practices in terms of segregation.

Table 9. Solid Waste Management Practices in Terms of Segregation

\begin{tabular}{|c|c|c|c|c|c|c|c|}
\hline \multirow[t]{2}{*}{ No } & \multirow[t]{2}{*}{ Descriptions } & \multicolumn{4}{|c|}{$\underline{\text { Responses }}$} & \multirow[t]{2}{*}{ GWA } & \multirow{2}{*}{$\begin{array}{l}\text { Interpreta } \\
\text { tion }\end{array}$} \\
\hline & & Alwa ys & Often & Seldom & Never & & \\
\hline 1 & $\begin{array}{l}\text { Do you segregate biodegradable (paper, } \\
\text { banana peels, cardboard, and vegetables) } \\
\text { and non-biodegradable } \\
\text { (plastic, tin cans, and others)? }\end{array}$ & 185 & 34 & 23 & 9 & 3.57 & Very Good \\
\hline 2 & $\begin{array}{l}\text { Do you segregate recyclable items for } \\
\text { collection? }\end{array}$ & 191 & 39 & 14 & 7 & 3.65 & Very Good \\
\hline 3 & $\begin{array}{l}\text { Do you segregate biodegradable (paper, } \\
\text { banana peels, cardboard, and vegetables) } \\
\text { and non-biodegradable }\end{array}$ & 185 & 34 & 23 & 9 & 3.57 & Very Good \\
\hline & (plastic, tin cans, and others)? & & & & & & \\
\hline
\end{tabular}

$\begin{array}{lll}\text { Weighted Mean } & 3.60 \quad \text { Very Good }\end{array}$

As reflected in the table, all of the practices in terms of solid waste segregation were interpreted as very good. The highest weighted average value of 3.65 is No. 2, "Do you segregate recyclable items for collection?". The least weighted average value is 3.25 that fell on No. 3, "Do you mix all the garbage (biodegradable and non-biodegradable) in one garbage container?" and No. 1, "Do you segregate biodegradable (paper, banana peels, cardboard, and vegetables) and nonbiodegradable (plastic, tin cans, and others)?". The weighted mean value was 3.60 interpreted as very good. It means that households have good practices in terms of waste segregations. Summary on solid waste management practices in terms of segregation is presented on Table 10.

Table 10: Summary on Solid Waste Management Practices of Households in Terms of Segregation

\begin{tabular}{|c|c|c|c|}
\hline Responses & Interpretation & Frequency & Percentage $(\%)$ \\
\hline Always & Very Good & 187 & 74.50 \\
\hline Often & Good & 36 & 14.34 \\
\hline Seldom & Fair & 20 & 7.97 \\
\hline Never & Poor & 8 & 3.19 \\
\hline \multicolumn{2}{|c|}{ Total } & 251 & $100 \%$ \\
\hline
\end{tabular}

As shown in the table, $74.50 \%$ or 187 households had very good practices in waste segregation, $14.34 \%$ or 36 had good segregation practices, $7.97 \%$ or 20 had fair practices and $3.19 \%$ or 8 had poor segregation practices. This presents that segregation of recyclable items, biodegradable and non-biodegradable are regularly practiced. Table 11 present the solid waste management practices in terms of composting and disposal.

\begin{tabular}{|c|c|c|c|c|c|c|}
\hline \multirow[t]{2}{*}{ No } & \multirow[t]{2}{*}{ Descriptions } & \multicolumn{2}{|c|}{$\underline{\text { Responses }}$} & & \multirow[t]{2}{*}{ GWA } & \multirow{2}{*}{$\begin{array}{l}\text { Interpreta } \\
\text { tion }\end{array}$} \\
\hline & & Often & Seldom & Never & & \\
\hline 1 & $\begin{array}{l}\text { Do you throw your garbage on } 155 \\
\text { garbage bins? }\end{array}$ & 30 & 44 & 22 & 3.27 & Very Good \\
\hline
\end{tabular}




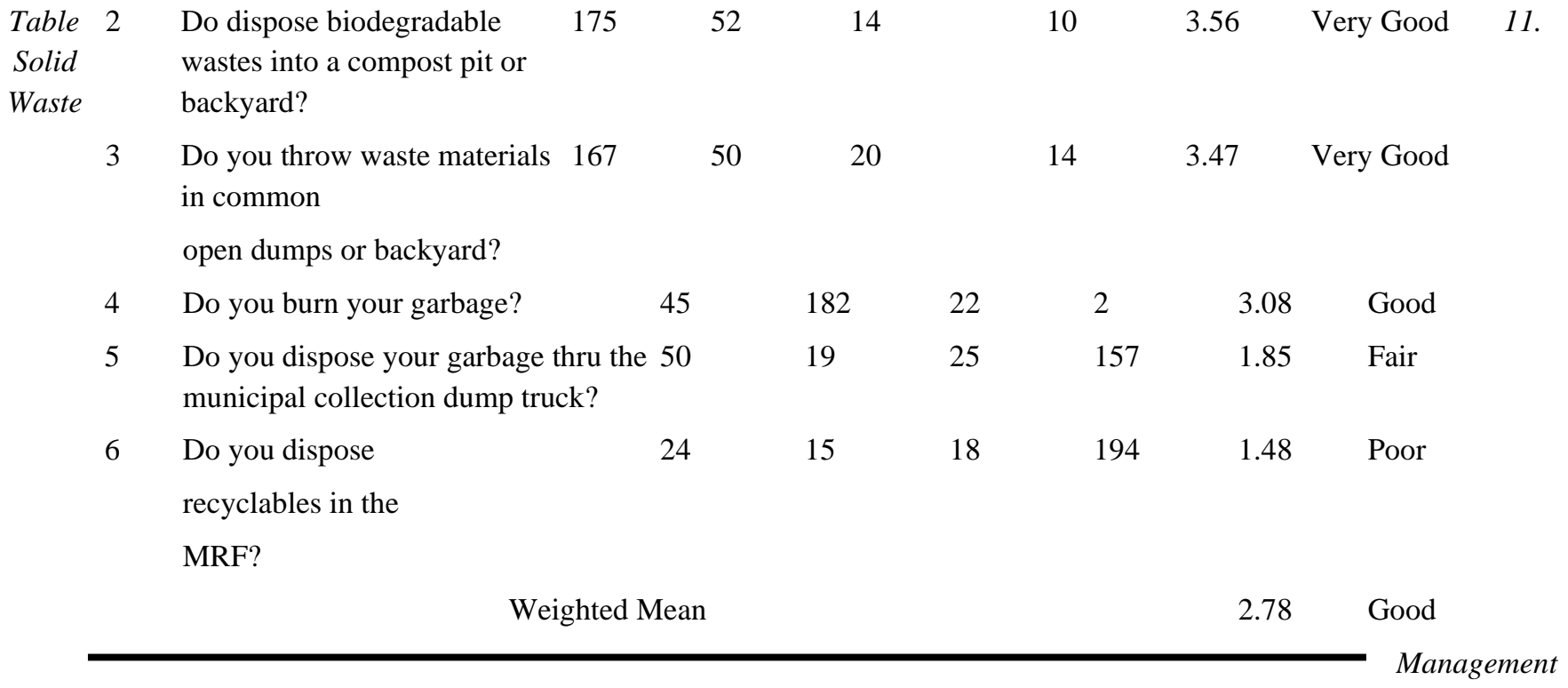

The table revealed that the highest weighted average value is 3.57 that fell on No. 2, "Do dispose biodegradable wastes into a compost pit or backyard?" and is interpreted as very good. The least weighted average is 1.48 that fell on No. 6 , Do you dispose recyclables in the MRF?" interpreted as poor. The weighted mean value is 2.78 interpreted as good. This implies that the households have good solid waste management practices in terms of composting and disposal. But they have poor practices in the disposing of recyclables in the MRF. Table 12 summarizes the solid waste management practices of households in terms of composting and disposal.

Table 12: Summary on Solid Waste Management Practices of Households in Terms of Composting and Disposal

\begin{tabular}{|c|c|c|c|}
\hline Responses & Interpretation & Frequency & Percentage $(\%)$ \\
\hline Always & Very Good & 103 & 41.03 \\
\hline Often & Good & 58 & 23.11 \\
\hline Seldom & Fair & 24 & 9.56 \\
\hline Never & Poor & 66 & 26.29 \\
\hline \multicolumn{2}{|c|}{ Total } & 251 & $100 \%$ \\
\hline
\end{tabular}

As shown in the table, out of 251 households $41.03 \%$ or 103 of them had good practices in composting and disposal, $23.11 \%$ or 58 households had good, $9.56 \%$ or 24 households and $26.29 \%$ or 66 households had fair and poor practices in composting and disposal respectively. It means that the households practice composting and proper waste disposal. Table 13 presents the effectiveness of Information Education Campaign and Programs on Solid Waste Management. 
Table 13. Effectiveness of IEC and Programs on Solid Waste Management

\begin{tabular}{|c|c|c|c|c|c|c|c|}
\hline \multirow[t]{2}{*}{ No } & \multirow[t]{2}{*}{ Descriptions } & \multicolumn{4}{|c|}{ Responses } & GWA & Interpreta \\
\hline & & Always & Often & Seldom & Never & & tion \\
\hline 1 & $\begin{array}{l}\text { Do you practice the waste } \\
\text { management campaigns and } \\
\text { programs of the barangay? }\end{array}$ & 164 & 42 & 35 & 10 & 3.43 & Very Good \\
\hline 2 & $\begin{array}{l}\text { Do you follow the signage } \\
\text { about waste disposal on } \\
\text { your barangay? }\end{array}$ & 173 & 35 & 37 & 6 & 3.49 & Very Good \\
\hline 3 & $\begin{array}{l}\text { Do you follow the waste } \\
\text { segregation (color scheme } \\
\text { of waste bins) on public } \\
\text { places? }\end{array}$ & 175 & 37 & 34 & 5 & 3.52 & Very Good \\
\hline 4 & $\begin{array}{l}\text { How often do you } \\
\text { receive flyers regarding } \\
\text { proper waste disposal? }\end{array}$ & 9 & 12 & 39 & 191 & 1.36 & Poor \\
\hline 5 & $\begin{array}{l}\text { Does the } \\
\text { barangay/municipal } \\
\text { government unit implement } \\
\text { campaigns on waste } \\
\text { management and clean up } \\
\text { drives? }\end{array}$ & 160 & 29 & 37 & 25 & 3.29 & Very Good \\
\hline
\end{tabular}

Weighted Mean $3.02 \quad$ Good

It was found out that the No. 3, "Do you follow the waste segregation (color scheme of waste bins) on public places?", had the highest weighted average has a value of 3.52 and is interpreted as very good. The lowest weighted average with value of 1.36 fell on No. 4, "How often do you receive flyers regarding proper waste disposal?" interpreted as poor. The weighted mean value was 3.02 interpreted as good. It implies that the IEC and Programs regarding solid waste management have good implementation. But it was found out that the distribution of flyers had poor implementation. Table 14 presents the summary of effectiveness of IEC and Implementation of Programs on solid waste management.

Table 14: Summary on Effectiveness of IEC and Programs on Solid Waste Management

\begin{tabular}{|c|c|c|c|}
\hline Responses & Interpretation & Frequency & Percentage $(\%)$ \\
\hline Always & Very Good & 136 & 54.18 \\
\hline Often & Good & 31 & 12.35 \\
\hline Seldom & Fair & 36 & 14.34 \\
\hline Never & Poor & 48 & 19.12 \\
\hline \multicolumn{2}{|c|}{ Total } & 251 & $100 \%$ \\
\hline
\end{tabular}

Based on the findings, out of 251 households $54.18 \%$ or 136 answered that the implementation of IEC and programs had very good rating, $12.35 \%$ or 31 rated as good, $14.34 \%$ or 36 as fair and $19.12 \%$ or 48 rated poor. 


\section{CONCLUSION}

Based on the results of the study, the following were the findings. The awareness of households was very high. Most of them were fully aware in the difference of biodegradable and non-biodegradable. But even with the knowledge on biodegradable and non-biodegradable, most of them were not aware on Republic Act 9003. The households had very good practices on solid waste management in terms of the 3 Rs (reduce, reuse, and recycle). The 3 Rs were regularly practiced by the households. In terms of composting and disposal, the households had good practices. But they have poor practices in terms of using the Material Recovery Facility (MRF). In the effectiveness and implementation of IEC and Solid Waste Management Programs of the Municipality and Barangay, the LGU had good implementation of such. It was only found out that distribution of flyers regarding RA 9003 and Solid Waste Management Programs is poor.

With the findings, the researchers came up with a general conclusion: the households practice proper waste management particularly the $3 \mathrm{Rs}$ (reduce, reuse and recycle) and proper waste composting and disposal even without their knowledge on RA 9003. Even with the presence of signage, Information Education Campaigns were limited on the part of households.

\section{RECOMMENDATIONS}

With the result of the efforts of the researchers, the following were then recommended for the improvement of the implementation of waste management: Municipal LGU in collaboration with the academe should provide enough signage and flyers to be distributed to every household. In addition, Municipal LGU in coordination with the Barangay LGU should have a campaign on Solid Waste Management Programs. Municipal and barangay ordinances should be added on flyers to be distributed. The Municipal LGU should maintain the collection of garbage on every barangay for the continuous Sustainable Waste Management.

\section{REFERENCES}

[1] Acosta , V., Paula, J., Lao, C., Aguinaldo, E. \& Valdez, M. (2012).

[2] Development of the Philippines National Solid Waste Management Strategy 2012-2016. The 7th International Conference on Waste Management and Technology. Procedia Environmental Sciences 16 ( 2012 ) 9-16.

[3] Azuelo, M. C., Barbado, L. N., and Reyes, L. L. 2016. Assessment of Solid Waste Management Strategies in Camarines Norte, Philippines. Asia Pacific Journal of Multidisciplinary Research, Vol. 4, No. 4. P-ISSN 23507756.
[4] Aquino, A. P., Deriquito, J. P., \& Festejo, M. A. (2013). Ecological Solid Waste Management Act: Environmental Protection Through Proper Solid Waste Practices.

[5] Department of Environment and Natural Resources. 2002.

[6] Japan International Cooperation Agency. 2008. THE STUDY ON

[7] RECYCLING INDUSTRY DEVELOPMENT IN THE REPUBLIC OF THE PHILIPPINES FINAL REPORT (SUMMARY). Retrieved on February 26, 2019 from http://open_jicareport.jica.go.jp/pdf/11882396.pdf.

[8] LGU Rizal. 2014. The Solid Waste Management Plan, Rizal, Kalinga.

[9] Paghasian, M. C. 2017. Awareness and Practices on Solid Waste Management among College Students in Mindanao State University Maigo

[10] School of Arts and Trades. Department of Humanities, Education and Social Sciences, Mindanao State University, Philippines. Advances in Social Science, Education and Humanities Research, volume 128 . Atlantis Press.

[11] RA 9003. 2000. The Ecological Solid Waste Management Act of 2000

[12] World Bank. 2001. Philippines Environment Monitor 2001: Solid Waste. The World Bank Group, Pasig City, Philippines. 